\title{
PELATIHAN GURU SEKOLAH LUAR BIASA (SLB) SISWA BUDHI SURABAYA DALAM MEMBENTUK KECAKAPAN HIDUP ABK MELAUI PEMBELAJARAN Pkn BERBASIS SIMULASI PERMAINAN TRADISONAL
}

\author{
Suhartono $^{(1)}$, Suhari ${ }^{(2)}$, Achmad Qomaru Zaman ${ }^{(3)}$ \\ PPKn, FKIP, UNIPA Surabaya \\ suhartono@unipasby.ac.id ${ }^{(1)}$ \\ suhari@unipasby.ac.id ${ }^{(2)}$ \\ qomaru@unipasby.ac.id ${ }^{(3)}$
}

\begin{abstract}
ABSTRAK
Kegiatan pengabdian pada masyarakat ini dilaksanakan dengan tujuan memberikan pelatihan bagi guru-guru yang mendampingi siswa berkebutuhan khusus di Sekolah Luar Biasa Siswa Budhi Surabaya dalam membangun SDM berdaya saing di Era Global dengan segala keterbatasan fisik yang dimiliki melalui pembelajaran PKn berbasis permainan tradisional. Bagaimanapun kekurangan fisik yang dimiliki oleh siswa Sekolah luar biasa Siswa Budhi mereka juga mempunyai Hak dan kesempatan yang sama sebagai warga negara Indonesia untuk berkembang dan berkarya seperti manusia normal pada umumnya. Skenario dari kegiatan pengabdian pada masyarakat ini dengan mempergunakan tes (pretest dan posttest design) dalam pelaksanaannya. Adapun Metode yang dipergunakan dalam kegiatan ini ialah pembelajaran Audio visual dan metode simulasi permainan tradisional. Jumlah peserta dalam kegiatan ini ada 8 orang guru SLB. Ada tiga sesi dalam kegiatan pelatihan ini. Sebelum dilaksanakan kegiatan para peserta diberikan tes awal mengerjakan beberapa soal yang sudah Tim siapkan, adapun tujuan pemberian tes di awal kegiatan ialah untuk mengetahui sejauh mana pengetahuan para peserta tentang pembelajaran PKn pada siswa berkebutuhan khusus. Hasil dari keseluruhan kegiatan PPM ini, dapat ditarik kesimpulan bahwa ada peningkatan pemahaman dan perbedaan cara mengajar yang dilakukan guru-guru pendamping siswa berkebutuhan khusus dalam pembelajaran PKn yang disampaikan kepada para siswa. Hal ini dapat diukur melalui nilai rata-rata tes awal sebanyak 65.28 dan setelah mengikuti pelatihan nilai rata-rata meningkat menjadi 72.75 .
\end{abstract}

Kata Kunci: Guru SLB, PKn, Permainan Tradisional 
PENDAHULUAN

Berakhirnya Reformasi 1998, tata kehidupan bangsa Indonesia mengalami berbagai pergeseran yang mendasar, pergeseran menuju kehidupan yang lebih demokratis di semua lini kehidupan warga negaranya. Diantara pergeseran itu antara lain terjadi pada bidang politik, ekonomi, sosial, dan dalam persaingan kehidupan global yang tidak ada sekat pembatas bagi siapa saja yang mampu bersaing dan berusaha, tidak terkecuali bagai mereka yang mengalami keterbatasan baik fisik, maupun mental atau sering disebut dengan difabel/ABK.

(Jauhari, 2017) menyatakan bahwa Anak-anak berkebutuhan khusus mengalami masalah-masalah tertentu dalam kehidupannya , misalnya berkaitan dengan aspek sensorik, motorik, serta penerimaan dalam pembelajaran maupun perilakunya (Jauhari. 2017). Anak berkebutuhan khusus mengalami hambatan dalam merespon stimulus yang diterima/diberikan olah rangsangan sekitar yang datang padanya. Bahkan sebagian dari mereka memiliki sikap minder atau kurang percaya diri dengan kondisi yang mereka miliki, perasaan dan kondisi seperti itulah yang membuat mereka tidak dapat berkembang dan dan tidak mampu bersaing dalam segi kemampuan di era global dewasa ini.

Berkaitan dengan hal tersebut di atas, Tim PPM Pendidikan Pancasila dan
Kewarganegaraan berupaya memompa semangat dengan pendidikan Kewarganegaraan berbasis simulasi permainan tradisional bagi siswa berkebutuhan Khusus.

$$
\text { Menurut Winataputra }
$$

memaparkan bahwa "segala aktivitas pendidikan yang pada akhirnya harus menghasilkan perubahan perilaku yang lebih matang baik secara psikologis ataupun sosial...maka dari itu pokok dari pendidikan termasuk pendidikan kewarganegaraan ialah belajar" ini memperlihatkan bahwa Indonesia masih banyak yang harus diperbaiki, dalam membangun pendidikan kewarganegaraan bagi persekolahan ataupun pengembangan pendidikan bagi warga negara agar menjadi warga negara yang baik sebagai program yang menjadikan semua elemen warga negara yang berujung pada adanya perubahan perilaku mantap warga negara baik secara sosial, kultural atau sosiologis.

era Global saat ini masyarakat Indonesia juga bergerak dari struktur subsisten ke arah masyarakat yang industrial. Masyarakat yang tidak hanya memiliki berubah secara tatanan fisik, melainkan namun juga diimbangi dengan perubahan sikap, perilaku, nilai yang ditandai oleh efisiensi, daya saing, produktivitas, demokratis dan sebagainya.

Oleh karena itu memalui kegiatan pelatihan bagi guru Sekolah Luar Biasa ini 
diharapkan mampu memberikan perspektif yang baik sebagai upaya merespon permasalahan di atas khususnya bagi penyandang disabilitas/ABK.

\section{METODE}

Kegiatan ini merupakan kegiatan pengabdian pada masyarakat, dengan tujuan utamanya untuk meningkatkan kemampuan guru pendamping siswa berkebutuhan khusus mengenai pengajaran PKn berbasis permainan tradisional pada siswa ABK. Kegiatan pengabdian masyarakat dalam pelaksanaannya dibagi mejadi 3 (tiga) tahap antara lain; (1) persiapan, (2) pelaksanaan, (3) evaluasi.

1. Tahap Persiapan

Pada tahap ini tim PPM memotret keseluruhan objek sasaran kegiatan sebagaimana untuk dapat mempersiapkan hal-hal yang diperlukan dalam pelaksanaan kegiatan PPM. Dimulai dari proses merencanakan dengan alur aktivitas sebagai berikut:
a. Observasi lapangan
b. mengatur perizinan
c. Menyusun metode kegiatan
d. Membuat materi Kegiatan pelatihan.

2. Tahap Pelaksanaan

Rangkaian kegiatan pada tahap ini mengikuti desain pretest posttest design yang dikemukakan oleh (Sugiyono, 2015). Pada tahap ini diawali dengan pemberian pretest berupa soal, tujuannya untuk memberikan mengetahui pengetahuan awal tentang pemahaman guru-guru pendamping mengenai pembelajaran PKn berbasis permainan tradisional pada siswa sekolah Luar Biasa Siswa Budhi Surabaya. selanjutnya pemberian treatment sesuai dengan materi PPM. Materi bertujuan untuk menambah wawasan pengetahuan tentang pembelajaran PKn berbasis permainan Tradisional pada siswa SLB. Selanjutnya dilakukan posttest berupa soal yang harus dijawab kembali oleh peserta, hal ini bertujuan untuk mengetahui hasil (peningkatan atau penurunan) antara sebelum dan seusai Pelatihan diberikan oleh pemateri.

3. Evaluasi

Umpan balik atau feedback akan diberikan pada tahap ini dengan memperhatikan dari perolehan pretest dan post-test yang diberikan pada peserta pelatihan dalam tahap sebelumnya.

\section{HASIL DAN PEMBAHASAN}

Kegiatan Pengabdian Pada

Masyarakat dengan judul pelatihan guru sekolah luar biasa (SLB) Siswa Budhi Surabaya dalam membentuk kecakapan hidup ABK melaui pembelajaran PKn Berbasis simulasi permainan tradisonal didapatkan hasil sebagai berikut: 
1. Indentifikasi masalah

Indentifikasi masalah dimulai dengan melakukan kegiatan survei/observasi yang dilaksanakan di Sekolah Luar Bisa Siswa Budhi Surabaya. Pada Tahap ini Tim melakukan pengamatan dan dokumentasi berupa wawancara langsung terhadap 8 orang guru pendamping di SLB tersebut. Hasil observasi memberikan gambaran kepada tim bahwa dalam pelaksanaan Kegiatan Belajar Mengajar hanya melakukan aktivitas cenderung membosankan. Dari itu diperlukan pelatihan terhadap guru supaya KBM lebih inovatif dan menyenangkan bagi siswa SLB sesuai dengan kriteria yang mereka inginkan.

2. Menentukan metode pelaksanaan Adapun metode dalam pengabdian masyarakat ini menggunakan metode audio visual dan simulasi. Pemilihan metode tersebut dengan berbagai pertimbangan, diantaranya penentuan metode audio visual bermaksud agar dalam pelaksanaan KBM lebih menarik, hal ini sejalan dengan pendapat (Azimin, Sutisyana, \& Rahmat, 2014) yang menyatakan ada banyak daya tarik yang dapat dirasakan dalam pembelajaran yang menggunakan media audio visual. Sehingga kegiatan belajar yang dijalani tidak sekedar ceramah, akan tetapi melihat dan mendengarkan materi yang diajarkan melalui tayangan (visual) dan suara-suara (Audio) sehingga lebih menarik.

Selain penerapan media audio visual, kegiatan pelatihan juga dilaksanakan dengan simulasi. Sejalan dengan pendapat (Sumantri \& Permana, 2001) dimana mereka memaparkan bahwa penyajian pelajaran dengan memperagakan dan mempertunjukkan kepada peserta didik suatu proses dalam sebuah tahapan, situasi atau benda tertentu yang sedang dipelajari baik dalam bentuk yang sebenarnya maupun dalam bentuk replika/tiruan yang dipertunjukkan oleh guru. Kegiatan pengabdian Pada Masyarakat ini menerapkan simulasi permainan dengan memperagakan secara langsung/praktik aktivitas fisik contohnya adalah aktivitas fisik dengan pendekatan permainan seperti Monopoli, Gundu, Ular naga panjang yang melatih siswa SLB Toleran, Tertib, Pengaturan strategi, Sabar menunggu giliran, taat aturan serta penanaman sikap baik lainnya sebagai upaya menjadikan mereka 
warga negara yang baik Good citizenship.

3. Pembuatan Modul

Pembuatan Modul didasarkan pada hasil pada tahap observasi dan wawancara. dari pengolahan hasil tersebut didapati sebagian guru pendamping mendapatkan kesulitan dalam pelaksanaan pembelajaran PKn, oleh karena itu pendekatan permainan tradisonal dijadikan sebagai strategi untuk menanamkan moralitas baik dalam upaya membangun SDM unggul menjadi good citizenship sehingga dapat bersaing dengan segala keterbatasan yang dimiliki.

\section{Pre Test}

Pelaksanaan pre test dilakukan secara tertulis, masing-masing peserta diberi soal tes untuk dikerjakan sebelum kegiatan pelatihan diberikan. Adapun berikut ini merupakan data hasil pre test.

Tabel 1.

Data Pretest

\begin{tabular}{lll}
\hline No & Nama & Skor \\
\hline 1 & AMR & 55 \\
2 & AKM & 75 \\
3 & SMD & 65 \\
4 & MNJ & 60 \\
5 & TS & 65 \\
6 & RPH & 70 \\
7 & ARM & 60 \\
8 & SRH & 65 \\
\hline Mean & 64.36 \\
Median & 65 \\
Max & 75 \\
\hline
\end{tabular}

\begin{tabular}{lc} 
& \\
Min & 55 \\
Std. Deviation & 6.235 \\
\hline
\end{tabular}

Berdasarkan table.1 dapat diuraikan bahwa nilai rata-rata hasil pre test diperoleh angka sebesar 64.36 dan standar deviasi sebesar 6.235, adapun nilai tengah 65 , skor nilai maksimal ialah 75 , nilai minimal ialah sebesar 55 .

5. Pelaksanaan Pelatihan

Pelaksanaan kegiatan pelatihan dilakukan pada hari Selasa tanggal 12 November 2019. mengambil tempat di gedung SLB SISWA BUDHI, dimulai pada pukul 08.00 WIB sampai dengan 15.30 WIB. Kegiatan registrasi peserta menjadi alur awal kegiatan, dan dilanjutkan sambutan dan pembukaan olah kepala sekolah, selanjutnya peserta mengerjakan soal pre test. Penyampaian materi oleh pemateri menyambung kegiatan berikutnya.

6. Pelaksanaan Post test

Setelah pemaparan materi. Peserta pelatihan diberikan lembar soal Post test untuk dikerjakan, soal Post test sama dengan soal yang diberikan pada saat pre test. Berikut ini adalah hasil post test peserta pelatihan.

Table 2.

Data Post test

\begin{tabular}{lll}
\hline No & Nama & Skor \\
\hline 1 & AMR & 72 \\
2 & AKM & 70 \\
3 & SMD & 65 \\
4 & MNJ & 70 \\
5 & TS & 75
\end{tabular}




\begin{tabular}{lcc}
\hline 6 & RPH & 70 \\
7 & ARM & 70 \\
8 & SRH & 80 \\
\hline Mean & 70.64 & \\
Median & 70 & \\
Max & 80 & \\
Min & 60 & \\
Std. Deviation 5.632 & \\
\hline
\end{tabular}

Berdasarkan table.2 diperoleh hasil bahwa nilai rata-rata hasil Post test sebesar 70.64 dan standar deviasi sebesar 5.632, sedangkan nilai tengah 70 , nilai tertingginya sebesar 80 , nilai terendah nya sebesar 60.

\section{Tahap Evaluasi}

Tahap ini merupakan kegiatan akhir dari seluruh rangkaian kegiatan PPM. Aktivitas dalam kegiatan ini ialah memaparkan hasil pelatihan dalam kegiatan PPM. antara lain: memberitahukan hasil perolehan nilai komparasi dari tahapan pre test dan nilai post test. menyimpulkan dari hasil kegiatan tersebut, bahwa nilai peserta pelatihan mengalami kenaikan, dilihat dari nilai rata-rata awal sebesar 64.36 setelah mengikuti pelatihan nilai rata-rata naik menjadi 70.64. namun begitu, berdasarkan bukti hasil perhitungan para pemateri menyempatkan diri memberi masukanmasukan yang berkaitan dengan inovasi aktivitas pembelajaran kepada guru-guru SLB khususnya dalam hal pembelajaran PKn.

\section{Simpulan}

Kesimpulan yang dapat ditarik dalam kegiatan Pengabdian Pada Masyarakat ialah pemahaman guru pendamping tentang inovasi dan modifikasi aktivitas pembelajaran PKn berbasis simulasi permainan Tradisional untuk anak berkebutuhan khusus meningkat.

\section{DAFTAR PUSTAKA}

Ace Suryadi. (2003). Pendidikan, Investasi SDM dan Pembangunan. Jakarta: Balai Pustaka.

Jauhari, M. N. (2017). PENGEMBANGAN SEKOLAH INKLUSIF DENGAN MENGGUNAKAN INSTRUMEN INDEKS FOR INCLUSION. Buana Pendidikan: Jurnal Fakultas Keguruan Dan Ilmu Pendidikan, 13(23), 18-27.

Sugiyono, P. D. (2015). Metode penelitian dan pengembangan. Res. Dev. D, 2015, 39-41.

Sumantri, M., \& Permana, J. (2001). Strategi belajar mengajar. Bandung: CV Maulana, 101-102.

Winataputra, Udin. (2008). Multikulturalisme-Bineka Tunggal Ika dalam Perspektif PKn Sebagai Wahana Pembangunan Karakter Bangsa Indonesia. Dalam "Acta Cicvicus, Jurnal Pendidikan Kewarganegaraan, Sekolah Pasca Sarjana UPI. Volume 2, No. 1 Oktober 2008 . 